\title{
EFEKTIVITAS AIR PERASAN BELIMBING WULUH (AVERRHOA BILIMBI L) TERHADAP MORTALITAS LARVA CULEX SP
}

\author{
${ }^{1}$ Cecep Dani Sucipto, ${ }^{2}$ Makhabbah Jamilatun, ${ }^{1}$ Ahmad Rio Fatullah \\ ${ }^{1}$ Politeknik Kesehatan Kemenkes Banten \\ ${ }^{2}$ Poltekkes Kemenkes Surakarta \\ Korespondensi : cecep.sucipto@poltekkesbanten.ac.id
}

\begin{abstract}
The spread of filariasis based on data from Banten Provincial Public Health Office in 2012, there were 192 cases of filariasis. Culex sp eradication as one of the vectors of filariasis disease can be done using larvacides. One alternative larvacide using natural ingredients, juice of bilimbi (Averrhoa bilimbi L). The purpose of this research is to determine the power to kill the juice of bilimbi and know a more effective concentration to kill larvae of Culex sp. This research uses five conscentration variation is 3\%, 3.5\%, 4\%, 4.5\%, 5\%. Concentration of bilimbi juice with methode diluting the juice of bilimbi leaves, observation were made after adding the juice of bilimbi leaves for 24 hours. The result showed juice of bilimbi leaves can kill Culex sp larvae within 24 hours, the concentration of equally effective in this research was 5\% with 99\% Mortality. This reaserach proved the juice of bilimbi leaves can kill Culex sp and equally effecvtive concentration of $5 \%$.
\end{abstract}

Keywords: Belimbing Wuluh (Averrhoa bilimbi L), Filariasis, Larva Culex sp

\begin{abstract}
ABSTRAK
Penyebaran filariasis berdasakan data dari Dinas Kesehatan Provinsi Banten Tahun 2014 tercatat sebanyak 192 kasus filariasis. Pemberantasan Culex sp sebagai salah satu vektor penyakit filariasis dapat dilakukan dengan penggunaan larvasida. Salah satu alternatif larvasida dengan menggunkan bahan alami yaitu air perasan belimbing wuluh (Averrhoa bilimbi L). Tujuan penelitian ini yaitu untuk mengetahui daya bunuh air perasan belimbing wuluh serta mengetahui konsentrasi yang paling efektif membunuh larva Culex sp. Penelitian ini menggunakan 5 variasi konsentrasi yaitu 3\%, 3.5\%, 4\%, 4.5\%, 5\%. Konsentrasi didapatkan dengan pengenceran air perasan belimbing wuluh dalam $100 \mathrm{ml}$ aquadest, pengamatan dilakukan setelah penambahan dengan air perasan belimbing wuluh selama 24 jam. Hasil penelitian menunjukan air perasan belimbing wuluh dapat membunuh larva Culex $s p$ dalam 24 jam. Konsentrasi paling efektif pada penelitian ini adalah 5\% dengan jumlah mortalitas larva 99\%. Penelitian ini membuktikan air perasan belimbing wuluh dapat membunuh larva Culex sp dengan konsentrasi efektif yaitu 5\%.
\end{abstract}

Kata Kunci: Belimbing Wuluh (Averrhoa bilimbi L), Filariasis, Larva Culex sp

\section{PENDAHULUAN}

Filariasis merupakan penyakit menular yang masih menjadi masalah kesehatan masyarakat di Indonesia karena berjangkit di sebagian besar wilayah Indonesia dan dapat menimbulkan kecacatan seumur hidup. ${ }^{[1]}$ Nyamuk genus Culex merupakan nyamuk yang banyak terdapat di sekitar kita. Nyamuk ini termasuk serangga yang beberapa spesiesnya terbukti berperan 
sebagai vektor penyakit. Culex berperan sebagai vektor penyakit yang penting seperti West Nile Virus, filariasis, Japanese enchepalitis, St Louis encephalitis. ${ }^{[2]}$

Berdasarkan laporan tahun 2009, tiga provinsi dengan jumlah kasus terbanyak filariasis adalah Nangroe Aceh Darussalam (2.359 orang), Nusa Tenggara Timur (1.730 orang) dan Papua (1.158 orang). Tiga Provinsi dengan kasus terendah adalah Bali (18 orang), Maluku Utara (27 orang), dan Sulawesi Utara (30 orang). ${ }^{[3]}$ Data Dinas Kesehatan Provinsi Banten Tahun 2012, Kabupaten Tangerang adalah Kabupaten dengan jumlah kasus terbanyak di Provinsi Banten yaitu 33 kasus, lalu diikuti Kota Serang dengan 23 kasus dan Kota Tangerang Selatan sebanyak 19 kasus, sedangkan Kabupaten Lebak merupakan Kabupaten dengan jumlah kasus yang paling sedikit yaitu hanya 1 kasus. $^{[4]}$

Pemberantasan filariasis dilakukan dengan pengobatan masal dan pemberantasan vektor. Saat ini strategi pemberantasan vektor lebih memperhatikan lingkungan, disebut Integrated Vector Management (IVM) dengan melakukan manajemen lingkungan dan pemberantasan biologis. ${ }^{[5]}$ Pengendalian vektor hampir di semua negara dan daerah endemis tidak tepat sasaran, tidak berkesinambungan dan belum mampu memutus rantai penularan

Hal ini disebabkan metode yang diterapkan belum mengacu kepada data/informasi tentang vektor, disamping itu masih mengandalkan kepada penggunaan insektisida dengan cara penyemprotan dan larvasidasi. ${ }^{[6]}$ Salah satu upaya yang dapat dilakukan untuk membatasi penyebaran penyakit adalah dengan mengendalikan kepadatan populasi vektornya sampai di bawah ambang kendali. Namun pemakaian insektisida secara terus menerus dapat mengakibatkan keracunan pada manusia, hewan ternak, polusi lingkungan, dan serangga menjadi resisten. Pada umumnya nyamuk diberantas dengan cara penyemprotan menggunakan insektisida sintesis sebagai racun serangga. Obat nyamuk semprot, obat nyamuk bakar, atau obat anti nyamuk yang dioleskan, tentunya mengandung insektisida yang mengandung beberapa senyawa kimia. Bagi warga yang tidak tahan, insektisida ini menimbulkan bau yang menyengat dan bisa menimbulkan sesak napas atau alergi pada kulit sehingga akan berpengaruh terhadap kesehatan. ${ }^{[2]}$

Salah satu cara pemberantasan Culex sp. yang dapat dilakukan secara sederhana dan tidak menimbulkan 
dampak negatif terhadap lingkungan adalah pemberantasan larva menggunakan senyawa kimia alami. Oleh karena itu, perlu diupayakan adanya insektisida alternatif yang berupa senyawa kimia alami yang berasal dari tumbuh-tumbuhan serta ramah lingkungan. ${ }^{[2]}$ Hasil penelitian Surya Nopianti (2008) menunjukan bahwa air perasan belimbing wuluh (Averrhoa bilimbi L) mempunyai pengaruh terhadap daya bunuh tehadap larva Anopheles aconitus dosis $4 \%$ merupakan perlakuan terbaik dengan rata-rata kematian $100 \% .^{[9]}$

Tanaman belimbing wuluh (Averrhoa bilimbi L) telah dimanfaatkan sebagai obat tradisional. Adapun kandungan senyawa aktif belimbing wuluh terdiri dari saponin, tannin, sulfur, glukosida, kalsium oksalat, asam format, dan peroksida. ${ }^{[7]}$ Saponin merupakan golongan senyawa triterpennoid yang dapat digunakan sebagai insektisida. Pengaruh saponin terlihat pada gangguan fisik serangga bagian luar, yakni mencuci bagian luar yang melindungi tubuh serangga sehingga menyebabkan kematian karena kehilangan banyak cairan tubuh. Saponin juga dapat masuk melalui organ pernafasan dan menyebabkan membran sel rusak atau proses metabolisme terganggu ${ }^{[8]}$

Berdasarkan kandungan senyawa aktif tersebut, maka peneliti juga ingin mengetahui apakah air perasan buah belimbing wuluh (Averrhoa bilimbi L) mempunyai daya larvasida terhadap larva Culex sp, berdasarkan hasil uji pendahuluan yang telah dilakukan oleh peneliti dengan menggunakan dosis yaitu $0 \%$ (kontrol negatif), $0,5 \%, 0,6 \%, 0,7 \%, 0,8 \%, 0,9 \%$, $1 \%, 1,5 \%, 2 \%, 2,5 \%, 3 \%, 3,5 \%, 4 \%, 4,5 \%$, 5\%. Didapatkanlah dosis yang akan digunakan pada saat uji sebenarnya adalah $0 \%$ (kontrol negatif), 3\%, 3,5\%, 4\%, 4,5\%, $5 \%$.

\section{METODE}

Desain penelitian yang akan dilakukan adalah eksperimen, dimana objek peelitian ini dibagi menjadi dua kelompok perlakuan. Kelompok pertama disebut sebagai kelompok perlakuan yaitu kelompok yang diberi air perasan belimbing wuluh (Averrhoa bilimbi L) dengan dosis yang berbeda. Kelompok yang kedua disebut sebagai kelompok kontrol negatif, yaitu kelompok yang tidak diberi air perasan belimbing wuluh (Averrhoa bilimbi L). ${ }^{[9]}$

Populasi pada penelitian ini digunakan buah belimbing wuluh (Averrhoa bilimbi L).Sampel pada penelitian ini adalah air perasan belimbing wuluh (Averrhoa bilimbi L) sebanyak 300 gram dengan konsentrasi 3\%, 3,5\%, 4\%, $4,5 \%$, dan $5 \%$. 
Pengolahan data dilakukan dengan cara : (1) Editing yaitu mengkoreksi data yang diperoleh dari hasil pengamatan dengan mengulang data hasil observasi pada masing-masing perlakuan untuk menghitung jumlah larva yang mati, (2) Coding yaitu memberikan kode pada masing-masing sampel dan perlakuan, (3) Tarbulating yaitu menyusun data kedalam bentuk tabel, dan (4) Entry yaitu memasukan data dalam komputer. ${ }^{[9]}$ Analisis data yang dilakukan secara deskriptif untuk menggambarkan kondisi kontrol dan masing-masing perlakuan. Sedang ananlisis menguji hipotesis yang dilakukan dengan uji ANOVA. ${ }^{[9]}$

\section{HASIL DAN PEMBAHASAN}

Tabel 1 . Hasil Pengukuran Suhu dan $\mathrm{pH}$ Larutan Uji

\begin{tabular}{|c|c|c|c|}
\hline No & Dosis $(\%)$ & Suhu $\left({ }^{\circ} \mathrm{C}\right)$ & $\mathrm{pH}$ \\
\hline 1 & 0 & 26 & 7 \\
\hline 2 & 0 & 26 & 7 \\
\hline 3 & 0 & 26 & 7 \\
\hline 4 & 0 & 26 & 7 \\
\hline 5 & 0 & 26 & 7 \\
\hline 6 & 3 & 26 & 6 \\
\hline 7 & 3 & 26 & 6 \\
\hline 8 & 3 & 26 & 6 \\
\hline 9 & 3 & 26 & 6 \\
\hline 10 & 3 & 26 & 6 \\
\hline 11 & 3.5 & 26 & 5.7 \\
\hline 12 & 3.5 & 26 & 5.7 \\
\hline 13 & 3.5 & 26 & 5.7 \\
\hline 14 & 3.5 & 26 & 5.7 \\
\hline 15 & 3.5 & 26 & 5.7 \\
\hline 16 & 4 & 26 & 5.5 \\
\hline 17 & 4 & 26 & 5.5 \\
\hline 18 & 4 & 26 & 5.5 \\
\hline 19 & 4 & 26 & 5.5 \\
\hline 20 & 4 & 26 & 5.5 \\
\hline 21 & 4.5 & 26 & 5.4 \\
\hline 22 & 4.5 & 26 & 5.4 \\
\hline 23 & 4.5 & 26 & 5.4 \\
\hline 24 & 4.5 & 26 & 5.4 \\
\hline 25 & 4.5 & 26 & 5.4 \\
\hline
\end{tabular}

\begin{tabular}{llll}
\hline \hline 26 & 5 & 26 & 5.3 \\
\hline 27 & 5 & 26 & 5.3 \\
\hline 28 & 5 & 26 & 5.3 \\
\hline 29 & 5 & 26 & 5.3 \\
\hline 30 & 5 & 26 & 5.3 \\
\hline \hline
\end{tabular}

Berdasarkan tabel 1 dapat diketahui bahwa suhu larutan uji pada kelompok kontrol dan perlakuan adalah sama yaitu $26^{\circ} \mathrm{C}$, sedangkan $\mathrm{pH}$ larutan pada kelompok dan perlakuan berkisar antara 5,3-7.

Tabel 2 Jumlah Rata-rata Mortalitas Larva Culex sp Setelah Pemaparan dengan Air Perasan Belimbing Wuluh

\begin{tabular}{|c|c|c|c|c|c|c|}
\hline \multirow[b]{2}{*}{$\begin{array}{l}\text { Pengulanga } \\
\mathrm{n}\end{array}$} & \multicolumn{6}{|c|}{$\begin{array}{c}\text { Jumlah Kematian Larva Pada Konsentrasi } \\
\text { Air Perasan Belimbing Wuluh }\end{array}$} \\
\hline & $\begin{array}{c}0 \% \\
\text { (Kontro } \\
1 \\
\text { Negatif) }\end{array}$ & $3 \%$ & $\begin{array}{c}3.5 \\
\%\end{array}$ & $4 \%$ & $\begin{array}{c}4.5 \\
\%\end{array}$ & $5 \%$ \\
\hline 1 & 0 & 12 & 14 & 17 & 18 & 20 \\
\hline 2 & 0 & 13 & 12 & 17 & 17 & 19 \\
\hline 3 & 0 & 11 & 14 & 15 & 18 & 20 \\
\hline 4 & 0 & 12 & 15 & 16 & 19 & 20 \\
\hline 5 & 0 & 12 & 14 & 15 & 19 & 20 \\
\hline Jumlah & 0 & 60 & 69 & 80 & 91 & 99 \\
\hline Rata-rata & 0 & 60 & 69 & 80 & 91 & 99 \\
\hline Persentase & $0 \%$ & $\begin{array}{l}60 \\
\%\end{array}$ & $\begin{array}{l}69 \\
\%\end{array}$ & $\begin{array}{l}80 \\
\%\end{array}$ & $\begin{array}{l}91 \\
\%\end{array}$ & $\begin{array}{l}99 \\
\%\end{array}$ \\
\hline
\end{tabular}

Berdasarkan Tabel 2. Dapat diketahui bahwa semakin tinggi konsentrasi maka semakin tinggi mortalitas larva Culex sp.

Penelitian ini bertujuan untuk mengetahui daya bunuh air perasan belimbing wuluh (Averrhoa bilimbi L) serta mengetahui konsentrasi berapa yang paling efektif membunuh larva Culex $s p$, dimana pada penelitian ini menggunakan 5 variasi konsentrasi yaitu 3\%, 3.5\%, 4\%, 4.5\%, $5 \%$. Konsentrasi didapatkan dengan pengenceran air perasan belimbing wuluh 
dalam $100 \mathrm{ml}$ aquadest, pengamatan dilakukan setelah penambahan dengan air perasan belimbing wuluh selama 24 jam.

\section{Suhu larutan uji}

Berdasarkan Tabel 4. dapat diketahui bahwa suhu air tempat perindukan adalah sama yaitu $26^{\circ} \mathrm{C}$, baik itu pada kelompok kontrol maupun pada kelompok perlakuan. Besar kecilnya konsentrasi yang digunakan dalam air perasan buah belimbing wuluh (Averhoa bilimbi $L$ ) tidak mempengaruhi suhunya.

Suhu air merupakan salah satu faktor yang dapat mempengaruhi faktor perkembangan dan kehidupan larva Culex $s p$ suhu air yang sesuai untuk perkembangan larva Culex sp antara 20$30^{\circ} \mathrm{C}$. ${ }^{[27]}$ Pada saat penelitian dapat dilihat hasil pengukuran yang telah dilakukan yaitu suhu air pada kelompok perlakuan dan kontrol sama sebesar $26^{\circ} \mathrm{C}$. Hal ini berarti suhu air yang digunakan berada dalam suhu yang normal untuk kehidupan larva nyamuk Culex sp.

\section{pH larutan uji}

Pada Tabel 1. dapat dilihat bahwa berbagai macam dosis yang digunakan yaitu $0 \%$ pada kelompok kontrol dan perlakuan dengan dosis mulai dari 3\%, $3.5 \%, 4 \%, 4.5 \%$ dan $5 \%$ tidak mempengaruhi $\mathrm{pH}$, yaitu 7 ( $\mathrm{pH}$ netral) yang berarti dimana kondisi $\mathrm{pH}$ air yang digunakan dalam penelitian adalah normal. Sedangkan pada perlakuan penelitian $\mathrm{pH}$ yang didapat pada konsentrasi yang tertinggi yaitu sebesar 6 , dimana $\mathrm{pH}$ air dalam kondisi asam. Menurut Hasil Penelitian Munif dkk (1997) larva dapat hidup dengan $\mathrm{pH}$ air 5,0-6,0. ${ }^{[28]}$

\section{Mortalitas larva Culex sp}

Berdasarkan Tabel 2. dapat dilihat bahwa pada kelompok kontrol saat penelitian tidak adanya kematian larva nyamuk Culex sp. Keefektivitasan air perasan belimbing wuluh (averrhoa bilimbi L) terhadap kematian larva nyamuk Culex $s p$ setelah 24 jam dengan dosis paling rendah $3,0 \%$ rata-rata kematian sebesar $60 \%$, dosis $3,5 \%$ sebesar $69 \%$, $4 \%$ sebesar $80 \%, 4,5 \%$ sebesar $91 \%$ dan $5 \%$ sebesar $99 \%$.

Pada Tabel 2. dapat dilihat, ada kenaikan antara kematian larva nyamuk dengan peningkatan penambahan jumlah dosis yang diberikan. Diawali dari kelompok kontrol yang sama sekali tidak ditemukan kematian hingga perlakuan dengan dosis tertinggi 5\% yang menunjukan rata-rata kematian sebanyak 99\%. Hal ini sesuai dengan pendapat Fitmaya (2006) yang menyatakan bahwa semakin tinggi dosis larvasida yang diberikan maka semakin tinggi pula rata- 
rata kematian larva nyamuk. ${ }^{[29]}$ Dapat dikatakan bahwa kematian larva uji dikarenakan kandungan senyawa kimia yang yang berada didalam air perasan belimbing wuluh (Averrhoa bilimb L). Kandungan senyawa kimia yang berada didalam air perasan belimbing wuluh (Averrhoa bilimb L) terdiri dari tanin dan saponin. ${ }^{[30]}$

Penelitian ini menggunakan larva nyamuk Culex sp instar III dan IV, karena sudah mempunyai alat-alat tubuh yang lengkap terbentuk dan struktur dinding tubuhnya belum mengalami pengerasan sehingga sehingga sesuai untuk perlakuan dengan senyawa tanin dan saponin. Pada penelitian ini mengunakan air perasan belimbing wuluh. Cara perasan digunakan untuk memperoleh sari perasan sebagai material awal digunakan tumbuhan segar yang dihaluskan. Sari perasan adalah larutan dalam air dan memiliki seluruh bahan yang terkandung dalam tumbuhan segarnya, sebanding dengan material awalnya yang tetap tinggal hanyalah bahan yang tidak terlarut. Air perasan buah belimbing wuluh (Averrhoa bilimbi L) yang digunakan dalam pemelitian ini dilarutkan dengan menggunakan aquadest. ${ }^{[30]}$

Mekanisme kerja larvasida dalam membunuh larva adalah sebagai racun perut (stomach poison). Saponin dapat berikatan dengan protein dan lipid penyusun membran sel yang mengakibatkan struktur protein dan lipid mengalami perubahan. Protein dan lipid merupakan komponen penyusun membran sel, bila salah satu penyusun membran sel rusak maka tegangan permukaan menurun, hal ini menyebabkan terjadinya osmosis komponen intraseluler sehingga sel mengalami lisis. ${ }^{[20]}$

Tanin memengaruhi protein fungsional, yaitu enzim pencernaan (Protease dan lipase). Inaktivasi kerja enzim dapat mengganggu metabolisme sel yang berpengaruh pada ketersedian energi tubuh. Apabila kebutuhan energi tubuh larva tidak tercukupi dapat mengakibatkan larva lemas yang lamakelamaan larva mati karena kehabisan energi. ${ }^{[20]}$

Mortalitas larva nyamuk Culex $s p$ memperlihatkan tanda-tanda sebagai berikut: larva tidak bergerak ketika diberikan rangsangan, tubuh larva berwarna putih atau kuning pucat, bentuk tubuh memanjang dan kaku.. ${ }^{[31]}$

Berdasakan Tabel 2. diketahu bahwa dosis yang dapat mematikan 99\% larva nyamuk Culex sp terdapat pada dosis $5 \%$. Menurut komisi pestisida Departemen Pertanian (1995) penggunaan larvasida 
dikatakan efektif apabila dapat mematikan $90-100 \%$ larva uji. ${ }^{[30]}$

\section{SIMPULAN}

Berdasarkan hasil dan pembahasan dapat disimpulkan hal-hal sebagai berikut; Air perasan belimbing wuluh (Averrhoa bilimbi L) efektif terhadap mortalitas larva Culex $s p$ instar III dan IV yaitu dosis $0 \%$ tidak ada kematian, dosis 3\% rata-rata kematian larva nyamuk $60 \%$, dosis $3,5 \%$ sebesar $69 \%, 4 \%$ sebesar $81 \%$, 4,5\% sebesar $90 \%$ dan $5 \%$ sebesar $99 \%$ dan dosis penambahan air perasan belimbing wuluh (Averrhoa bilimbi $L)$ yang paling efektif untuk membunuh larva Culex sp adalah 5\%.

\section{DAFTAR PUSTAKA}

1. Kementerian Kesehatan, Permenkes RI, No.1582/Menkes/SK/IX/2005, Tentang Penanggulangan Filariasis., Jakarta : Kemenkes. 2014.

2. Rahmawati, Elma et al. "Pemanfaatan Biji Mimba (Azadirachta indica) Sebagai Larvasida Nyamuk Culex sp." LenteraBio 2.(3),207-210. 2013.

3. Pusat Data Surveilans Epidemiologi Kementerian Kesehatan RI. Filariasis di Indonesia. Buletin Jendela Epidemiologi. Juli 2010; Volume 1.

4. Dinas Kesehatan Provinsi Banten. Profil Kesehatan Provinsi Banten., Jakarta : Kementrian Kesehatan Republik Indonesia. 2012.

5. Ismail, Gani Yogi. "Efek Residu Bacillus thuringiensis israelensis terhadap Aedes Albopictus dan Culex quenquefasciatus di Dalam Bak Fiber Glass, Keramik dan Semen. [Skripsi].
Fakultas Kedokteran. Universitas Indonesia. 2011.

6. Ditjen PP dan PL. Petunjuk Teknis Jumantik - Pemberantasan Sarang Nyamuk., Kementrian Kesehatan Republik Indonesia: Jakarta. 2014.

7. Safitri, Khairina. "Pengaruh Ekstrak Belimbing Wuluh (Averrhoa bilimbi L) Sebagai Penggumpal Lateks Terhadap Mutu Karet." [Skripsi]. Fakultas Matematika dan Ilmu Pengetahuan Alam Univeristas Sumatra Utara. 2009.

8. Nopianti, Surya. "Efektivitas Air Perasan Belimbing Wuluh (Averrhoa bilimbi L) Terhadap Kematian Larva Nyamuk Anopheles aconitus Instar III". [Skripsi]. Fakultas Ilmu Kesehatan. Universitas Muhammadiyah Surakarta. 2008.

9. Nopianti, Surya et al. "Efektivitas Air Perasan Belimbing Wuluh (Averrhoa bilimbi L) Terhadap Kematian Larva Nyamuk Anopheles aconitus Instar III", Jurnal Kesehatan , ISSN 1976-7621 1.(2),103-114. 2008.

10. Widodo, Hendra. Parasitologi Kedokteran. Jogjakarta. Penerbit : DMedika. 2013

11. Wicaksono, S.A. "Pengaruh Pencucian Payung Yang Dicelup Insektsida Permethrine Terhadap Daya Bunuh Larva Culex sp". [Skripsi]. Fakultas Ksehatan Masyarakat. Universitas Muhammadiyah Semarang : Semarang. 2010.

12. Astuti M.A.W. "Uji Daya Bunuh Ekstrak Bunga Kecombrang (Nicolaia speciosa (Blume) Horan) Terhadap Larva Nyamuk Culex quenquefasciatus Say." [Skripsi]. Fakultas Teknobilogi. Universitas Atma Jaya Yogyakarta : Yogyakarta. 2011.

13. Solichah, Zumrotus. "Ancaman Dari Nyamuk Culex sp Yang Terabaikan". BALABA, 5.(1),21-23. 2009.

14. Ardra. C.T. "Perbandingan Prevalensi Mikrofilaria Antara Pemeriksaan Mikroskopik Dengan Brugia Rapid". 
[Skripsi]. Fakultas Kedokteran Universitas Indonesia. Jakarta. 2009.

15. Sucipto, C.D. Vektor Penyakit Tropis. Yogyakarta. Penerbit : Goysen Publishing. 2011.

16. Pusat Data Surveilans Epidemiologi Kementerian Kesehatan RI. Buletin Jendela Epidemiologi Demam Berdarah Dengue. Agustus 2010; Volume 2.

17. Jannah, Rahmawati Nur. "Uji Efektifitas Ekstrak Daun Sirsak (Annona muricata) Sebagai Pestisida Nabati Terhadap Pengendalian Hama Tanaman Sawi (Brassica Juncea)". [Skripsi]. Fakultas Keguruan dan Ilmu Pendidikan Universitas Muhammadiyah Surakarta. 2010.

18. Rahayu, Puji. "Konsentrasi Hambat Minimum (KHM) Buah Belimbing Wuluh (Averrhoa bilimbi L) Terhadap Pertumbuhan Candida albicans". [Skripsi]. Fakultas Kedokteran Gigi Universitas Hasanudin. 2013.

19. Kristianto, Aries. "Pengaruh Ekstak Kasar Tanin Dari Daun Belimbing Wuluh (Averrhoa Bilimbi L) Pada Pengolahan Air". [Skripsi]. Fakultas Matematika dan Ilmu Pengetahuan Alam Universitas Jember. 2013.

20. Pratwi, Y.C. et al. "Efektivitas Ekstrak daun Ceremai (Phyllanthus achidus) Terhadap Mortalitas Larva aedes aegypty”. LenteraBio 3.(2),197-201. 2013.

21. Taslmah. "Uji Efikasi Ekstrak Biji Srikaya (Annona squmosal. L) Sebagai Bioinsektisida Dalam Upaya Integrated Vector Management Terhadap Aedes aegypty". [Skripsi]. Fakultas Kedokteran dan Ilmu Kesehatan Universitas Islam Negri Syarif Hidayatullah Jakarta. 2014.

22. Aradila, A.S. "Uji Efektivitas Ekstrak Etanol Daun Mimba (Azadirachta indica) Terhadap Larva Aedes aegypty". [Skripsi]. Fakultas
Kedokteran Universitas Diponegoro Semarang. 2009.

23. Hadiyan et al. "Efek Larvasida Ekstrak Etanol Daun Mahkota Dewa (Phaleria macrocarpa) Terhadap Larva Aedes aegypty". Jurnal Parasitologi 6,(1).3435, 2013.

24. Pratiwi, Ameliana. "Studi Deskroptif Penerimaan Masyarakat Terhadap Larvasida Alami". [Skripsi]. Fakultas Ilmu Keolahragaan Jurusan Kesehatan Masyarakat Universitas Negri Semarang. 2013.

25. Wijayanti, Tri. "Vektor dan Reservoir". BALABA. Ed.007, 18,(02). 2008.

26. Ermi ML. "Malaria, Pembunuh Terbesar Sepanjang Abad." 2005. http://www.indomedia.com/poskup/20 06/05/15/edisi5/0pini. htm : Diakses 30 Mei 2016.

27. Munif et al. Penebaran Kanidiospora Metarrhizum anisopliae Untuk Penanggulangan Populasi Larva Anopheles aconitus di Persawahan Renjasari, Banjanegara Pusat Penelitian Ekologi Kesehatan Badan Penelitian dan Pengembangan Depkes RI. Jakarta. 1997 http:///www.kalbe.co.id/files/cdk/files/ diakses 30 Mei 2016.

28. Fitmaya, A. "Uji Aktivitas Larvasida Ekstrak Etanol 96\% Daun Belimbing Manis (Averrhoa carambola L.) Terhadap Larva Nyamuk Anopheles aconitus Instar III dan Kromatografi Lapis Tipisnya." Skripsi, Surakarta: Fakultas Farmasi UMS. 2006.

29. Komisi Pestisida. Metode Standar Pengujian Efikasi Pestisida, Jakarta : Departemen Pertanian, 1995.

30. Kaihena, Martha et al. "Efektivitas Ekstrak Etanol Daun Sirh (Piper betle L) Terhadap Mortalitas Larva Nyamuk Anopheles sp dan Culex sp" Jurnal Kedokteran dan Kesehatan , ISSN 1979-6358 4.(1),89-104. 2012. 